\title{
Management of Pond Entrepreneurship: Case Study at Al-Mukhlisin Orphanage Islamic Boarding School Foundation
}

\author{
H.M.Noer ${ }^{1 *}$, Armai Arief $^{2}$, Sumargono ${ }^{3}$ \\ ${ }^{1}$ Doctor of Islamic Education Managemen Postgraduate Program, University of Muhammadiyah Jakarta, Indonesia \\ ${ }^{2,3}$ Postgraduate Program, University of Muhammadiyah Jakarta, Indonesia
}

DOI: $\underline{10.36348 / \text { sjhss.2020.v05i10.004 }}$

| Received: 13.09.2020 | Accepted: 24.09.2020 | Published: 08.10.2020

*Corresponding author: H.M.Noer

\section{Abstract}

The existence of pesantren in responding to the development time to be able to give birth to reliable santri empowerment through the power of the brain (thinking), heart (faith), and hands (skills) is the main asset to form a santri personality capable of balancing to the development of time. Various skill activities in the form of trainings or workshops (daurah) which further deepen knowledge and work skills are the effort to broaden the knowledge of santri in the field of entrepreneurship, which constitutes one of the concrete breakthroughs to prepare santri as an individual in the community. This research is directed to answer, investigate, and analyze the management of the pond entrepreneurship at the Orphanage Foundation/Pondok Pesantren Al Mukhlisin Ciseeng, Bogor. The results show that the fish pond entrepreneurship was carried out through extra-curricular activities the Orphanage Foundation/Pondok Pesantren Al Mukhlisin Ciseeng, Bogor.

Keywords: Management, entrepreneurship, pond, pesantren.

Copyright @ 2020: This is an open-access article distributed under the terms of the Creative Commons Attribution license which permits unrestricted use, distribution, and reproduction in any medium for non-commercial use (NonCommercial, or CC-BY-NC) provided the original author and source are credited.

\section{INTRODUCTION}

A pesantren plays a very important role in nation-building as one of the "legacies" of the oldest and most original Indonesian Islamic education institution [1]. Since its establishment, pesantren has always been involved in national affairs through fostering ulama/kiai who has powerful spirituality, strong faith, sincerity in fighting, and moral strength for the integrity of the Indonesian nation from efforts of setting against by the invaders.

At the beginning of its birth, pesantren grew, developed, and spread in various villages. The existence of pesantren as an Islamic institution which is highly associated with Indonesian characteristics has strategic values for the development of Indonesian society [2]. This is what supports the understanding that pesantren has a strong cultural base when it begins to influence the voices and desires of the rural Muslim community. Thereby, pesantren is essentially religious institution which is inseparable from society because of its growth and development by and for society. In this context, pesantren is basically an education which is full of social transformation styles. Pesantren activities are potential seeds that make it an alternative for community development and empowerment in Indonesia.

From time to time, pesantren has grown and developed, both quantitatively and qualitatively. Not do a few people see and hope that pesantren becomes an alternative education. Besides, with various educational system innovations being developed in pesantren and which are adopting a general education style, pesantren is increasingly competitive in providing education to the public. Although there have been various educational innovations, pesantren education has so far not lost its distinctive features which are different from the general education model formulated in the form of schools [3].

To play the role of education in providing quality human resources, pesantren must improve the quality and model of education. This is because the pesantren education model with a conventional system does not help much in providing human beings with inclusive skills in mastering both religious knowledge and general knowledge and technological skills [4]. 
In terms of management, pesantren with its diversity, includes unique educational institutions or organizations. This is because there are Kiai figures in pesantren who have extraordinary roles and authority, so from the point of view of management science, there are often contradictions or inconsistencies with the code of ethics. For example, in relation to the delegation of tasks and authority, authority, intervention issues, and others [5], however, there are pesantren that applies modern management well, such as the modern pesantren of Gontor Ponorogo and Az-Zaitun. With the application of modern governance in accordance with their knowledge, it appears that these two pesantren have progressed very rapidly (regardless of whether or not they agree with their respective educational content). However, it cannot be denied that most pesantren in this country have not implemented modern management according to their usual knowledge.

Furthermore, the advantages of pesantren lie in its ability to create a universal approach to life that is evenly followed by all santri, so they are more independent and not dependent on who and their community institutions [6]. According to Kuntowijoyo 91996: 249), one of the benefits of pesantren is the thought of being independent. Kuntowijoyo defines independence as the potential for organization, realizing local and community resources as key players, and getting the maximum benefit from development efforts.

Initially, pesantren was established without government interference in terms of funding, but exclusively by non-governmental organizations, so pesantren is often referred to as non-formal educational institutions which is all funded by the community. Pesantren education generally puts forward material on religion and morals, or at least vocational education, so many pesantren graduates often stutter when entering society.

These graduates have difficulty finding jobs that offer job opportunities, so most of them become informal workers rather than professionals such as traders in traditional markets. Many of them are unemployed after graduating, even though the money and time they spend studying at the pesantren is not small. It can take up to a dozen years, or about the same as those who received formal education before graduating. Indeed, like others, santri will face challenges that are no less complex in this era of global competition.
Seeing this situation, entrepreneurship education is one concrete step to further strengthen pesantren. In addition to the spirit of independence that has become his trademark, it is also important to teach santri various skills and an entrepreneurial spirit, so they can continue their life professionally after graduation.

The term entrepreneur was first used by Ricard Cantillon, originated from the French words entre, which means between, and pendre which means "to accept" or "to receive". These words are used to describe someone who "takes risks" (dare to take risks) between buyers and sellers, or someone who tries to "start" a new business [7].

According to Hendro, entrepreneurship as expressed by Baladina is a creative effort that creates values from what does not exist and which can be enjoyed by many people [8].

On the other hand, according to Abdullah Gymnastiar or who is familiarly called Aa Gym, as quoted by Sudrajat, he stated that "entrepreneurship is the ability of a person to obtain or create benefits from everything in himself and in the environment". Aa Gym also stated, "Entrepreneurship is not about doing business, it's about being able to grow potentials in ways that are beneficial to many people [9].

According to Hendro [10], every successful entrepreneur has four main elements as follows

a) Skills (relationship with IQ and skills) in: opportunities for reading, innovation, management, and sales.

b) Courage (in terms of emotional and mental intelligence) in: overcoming fear, controlling risks, and leaving comfort zones.

c) Persistence (which relates to self-motivation), which includes: persistence (resilient), never giving up, determination (being firm in one's beliefs), and soul strength.

d) Creativity, which precedes the idea of finding opportunities based on intuition (relationship with experience), generates inspiration.

According to Novan [11], there are values of personal advantages of an entrepreneur, namely: 1) selfconfidence; 2) originality; 3) people centered; 4) orientation to work results; 5) forward-looking; 6) courage to take risks. Reflections on the values of personal excellence are manifested in the following behaviors: 
Table-1: Enterpreneurship Indicators

\begin{tabular}{|l|l|l|}
\hline No & Enterpreneurship Values & Indicators \\
\hline 1 & Self-confidence & Trust, independence, individuality, optimism. \\
\hline 2 & Task and Result Oriented & $\begin{array}{l}\text { Need for performance, profit orientation, persistence and determination, } \\
\text { hard work, energy, initiative. }\end{array}$ \\
\hline 3 & Taking risks & $\begin{array}{l}\text { Acting as a manager, getting along with others, fancy of constructive and } \\
\text { critical suggestions. }\end{array}$ \\
\hline 4 & Creativity & Highly innovative creativity, flexible network. \\
\hline 5 & Forward-oriented & Having a forward perspective \\
\hline 6 & Honesty and hard-working & With the belief that life is work, and work is worship. \\
\hline
\end{tabular}

Source: Novan 2012

The importance of entrepreneurship as an alternative to economic development should be ideally developed not only in the business world, on campus, or at school, but also in pesantren. The important role that becomes a gift for entrepreneurs in the pesantren environment is that they get not only entrepreneurship knowledge, but also Islamic values and examples that they receive as santri. This can be a capital for santri to become entrepreneurs. One of the entrepreneurial activities at the Pondok Pesantren Al Mukhliisin is a fish pond.

\section{RESEARCH OBJECTIVE}

This study aims to answer, investigate, and analyze how the entrepreneurial management of the fish pond at the Orphanage Foundation/Pondok Pesantren Al Mukhlisin Ciseeng, Bogor.

\section{RESEARCH METHOD}

This research was carried out at the Orphanage Foundation/Pondok Pesantren Al Mukhlisin Ciseeng, Bogor. The method used is the case study. Data collection uses interview, observation, and document study techniques. Data analysis technique uses data reduction, data display, and conclusion drawing. The informants are the Head of the Foundation, Vice Head of the Foundation, Vice Head of Pondok, Head of Cooperatives, and Head of Administration for the Orphanage Foundation/Pondok Pesantren Al Mukhlisin Ciseeng, Bogor.

\section{RESULTS}

Entrepreneurship at Pondok Pesantren AlMukhlishin Ciseeng, Bogor, is basically a gathering place to strengthen the Islamic brotherhood of the large families of Pondok Pesantren Al-Mukhlishin whose authority status is semi-autonomous. All entrepreneurial activities are in one-stop-integrated to make it easier to control management, namely under the authority of Ibu Nyai Hj.Ir. Iin Indraningsih Abidin, as Head of Pondok Pesantren Al-Mukhlishin, respecting the decisions agreed upon in the meetings of each entrepreneurial board.

In accordance with the image of the boarding school which emphasizes independence rather than selfdependence, Al Mukhlisin provides various skills and an entrepreneurial spirit. One of them is to utilize a pond area of approximately $5000 \mathrm{~m}^{2}$ to raise carp, gold fish, catfish, and several other types of fish.

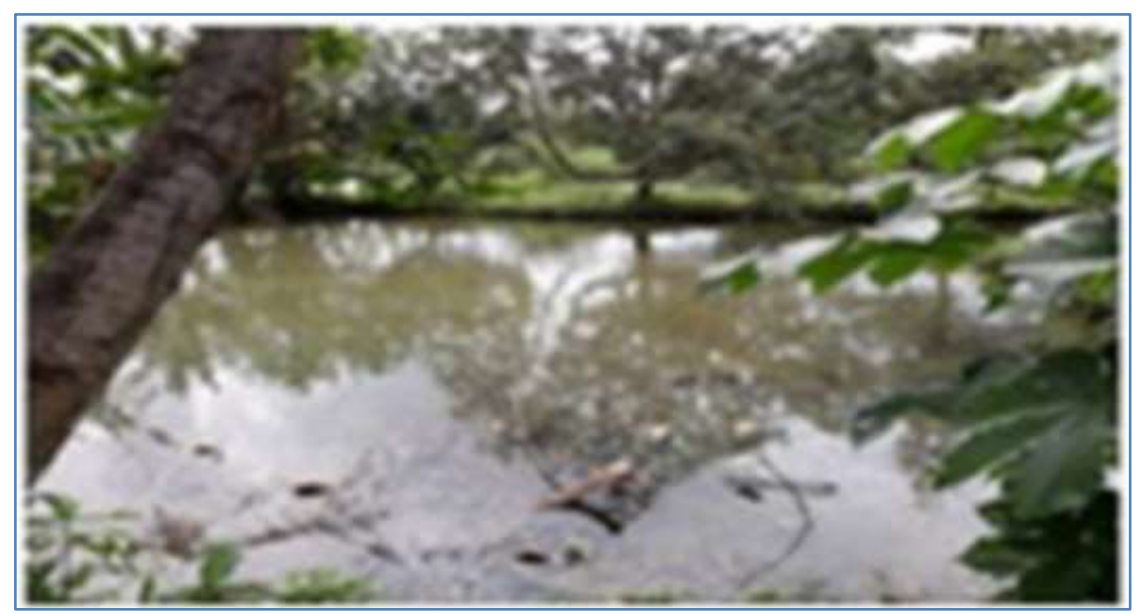

Fig-1: Fish Pond

Source: Personal Document

Entrepreneurship at Pondok Pesantren AlMukhlishin Ciseeng is an activity of santri included in the extracurricular skills of the Pondok, both the development of self-skills and entrepreneurial activity programs related to the real world of business, which hopefully will benefit the santri of Pondok Pesantren Al-Mukhlishin upon joining the community. 
In the curriculum of Pondok Pesantren AlMukhlishin, santri are not taught entrepreneurship material, this is due to the too tight learning schedule due to the integration of the 2013 curriculum with the pesantren curriculum. However, entrepreneurship learning is taught in extra-curricular activities on Saturdays and Sundays, and is a compulsory work program for the Al Mukhlishin Santri Association (IKSAN) to foster the self-potentials of santri in entrepreneurship. IKSAN's efforts in practice or implementing its work program are by cooperating with companies or holding santri workshops in the field of entrepreneurship.

Besides, Pondok Pesantren Al Muklisin also collaborated with the Trisakti University Islamic
Banking and Finance Institute (IBFI) to hold a seminar on sharia economics and business in fostering an entrepreneurial spirit and Islamic economy, with the information source from PT Bank Muamalat Indonesia. The purpose of holding this seminar is to awaken the spirit of jihad fitijaroh, the spirit of entrepreneurship, to open new opportunities, to know about entrepreneurial challenges, and to have sharia-based business ethics.

Management or entrepreneurship management at Pondok Pesantren Al-Mukhlishin Ciseeng is based on the results of an interview with Ustad Nanang (March 10, 2020), namely good policy steps to foster an independent entrepreneurial spirit with the following strategies:

Table-2: Steps of Entrepreneurship Policy in Pondok Pesantren Al Mukhlisin

\begin{tabular}{|l|l|l|}
\hline No & Strategies & Description \\
\hline 1 & First Step & $\begin{array}{l}\text { Discuseed in the meeting together, even in a seminar by inviting expert information sources } \\
\text { from outside Pondok Pesantren to get input on ideas that can revive the field of } \\
\text { entrepreneurship in the conditional environment of Pondok Pesantren Al-Mukhlishin } \\
\text { Foundation. }\end{array}$ \\
\hline 2 & Second Step & $\begin{array}{l}\text { The results are discussed together specifically to develop a suitable thought within Pondok } \\
\text { Pesantren Al-Mukhlishin to build a solid team work based on the principle of kinship. }\end{array}$ \\
\hline 4 & Fourth Step & $\begin{array}{l}\text { The Head of Pondok, Ibu. Nyai Ir. Iin Indraningsih Abidin delegates authority to an elected } \\
\text { head or coordinator who is appointed by consensus as a Business Sector Manager to seriously } \\
\text { manage, jointly run, control, and evaluate her business activities. }\end{array}$ \\
\hline 5 & Fifth Step & $\begin{array}{l}\text { The head of Pondok forms a special committee with the mandate and authorized to be } \\
\text { Mukhlishin Ciseeng. } \\
\text { enlightenment by Ibu. Nyai Ir. Iin Indraningsih Abidin, Head of Pondok Pesantren Al- } \\
\text { Mukhlishin to ensure success, and that they grow a sense of confidence in management and } \\
\text { optimistic that they can generate independence, and provide a progress report to the Head of } \\
\text { Pondok Pesantren to forward the report to the General Head of the Al-Mukhlishin Foundation } \\
\text { to be evaluated and followed up as deemed necessary developed its business field. }\end{array}$ \\
\hline
\end{tabular}

Source: Ustaz Nanang, 2020

\section{DISCUSSION}

Entrepreneurship education is one of the concrete steps to further empower pesantren. In addition to the spirit of independence that has become its trademark, it is also important to teach santri various skills and an entrepreneurial spirit, so after graduating they can continue their life by working professionally. Therefore, pesantren does not only teach religious sciences, but santri are also equipped with various hard skills and soft skills, the spirit of entrepreneurship, and information technology skills needed in modern society.

Bogor is an area with many fish ponds, and so is Ciseeng. This geographical condition creates business opportunities for Pondok Pesantren Al Mukhlisin. There are thirteen fish ponds managed by teachers, the community, and orphaned santri at Pondok Pesantren Al Mukhlisin, while the cultivated fish are are tilapia, catfish, and carp.
The implication of entrepreneurship management in the fish ponds have a direct impact on the financing of Islamic education at Pondok Pesantren Al Mukhlishin, to the board of Pondok, the board of business managers, the santri/students and the surrounding community. Even all users of Islamic education at Pondok Pesantren Al-Mukhlishin get blessings from the results of their entrepreneurial activities. The implications for santri/students, management, teacher councils and other partners can foster an entrepreneurial spirit.

Furthermore, the entrepreneurial-based economic development efforts provided at Pondok Pesantren Al-Mukhlishin can equip santri/students to open their entrepreneurial horizons by practicing science, technology, and various practical personal skills and their implications as a solution to prepare santri/students to become alumni with the spirit of independent santri, have the courage to try, like to 
collaborate in business partnerships, a spirit of business responsible for carrying out entrepreneurial activities.

Pondok Pesantren Al Mukhlishin has become a proportional forum for community empowerment. The community is nurtured and guided towards the creation of a social structure that is not only civilized but also civilized, by selecting new coming cultures. Saving the the worsd, realizing the dynamism of pesantren, as the Javanese proverb, angeli naging ora keli. The manifestation, among others, is that society is fostered into an honest and trustworthy economic society, a producer, a superior and respectable culture, encouraging people to become moral and civilized beings.

\section{CONCLUSION}

The steps taken by Pondok Pesantren Al Mukhlisin regarding entrepreneurship education included in the extra-curricular are very appropriate. Since this is something highly recommended in Islam, businesses are not just about profit and loss, but a vehicle that delivers to glory. Santri are equipped with entrepreneurial knowledge and skills with the following objectives:

1) Being able to provide knowledge to santris on ethics in business

2) Building the spirit of the santri participants to become independent young entrepreneurs who are creative in accordance with Islamic sharia

3) Directing santri interested in the world of entrepreneurship to become young entrepreneurs.

4) Creating the next generation of young entrepreneurs who can create jobs in order to build human resources for the nation and state.

\section{REFERENCE}

1. Ziemek, M. (1986). Pesantren dalam perubahan sosial. Perhimpunan Pengembangan Pesantren dan Masyarakat (P3M).

2. A'la, A., \& Pesantren, P. (2006). Yogyakarta. Penerbit Pustaka Pesantren.

3. Sulthon, M., Khusnuridlo, M., \& Tasnim, Z. (2006). Manajemen pondok pesantren dalam perspektif global. LaksBang PRESSindo.

4. Muhaimin. (2011). "Pesantren dalam Bingkai Mutu Pendidikan Global: Meretas Mutu Pendidikan Pesantren Masa Depan (Suatu Kata Pengantar)", dalam Umiarso dan Nur Zazin, Pesantren di Tengah Arus Mutu Pendidikan, Menjawab Problematika Kontemporer Manajemen Mutu Pesantren (Semarang: Rasail Media Group, 2011).

5. Asifudin, A. J. (2016). Manajemen Pendidikan untuk Pondok Pesantren. Manageria: Jurnal Manajemen Pendidikan Islam, 1(2), 355-366.

6. Wahid, A. (1999). Bunga Rampai Pesantren: Kumpulan Karya Tulis Abdurrahman Wahid. Jakarta: Dharma Bakti.

7. Cantilon, R., dalam, J. (2008). Winardi, Entrepreneur dan entrepreneurship, (Kencana Prenada Media Group, Jakarta 2008).

8. Baladina, N. (2012). Analisis Struktur, Perilaku, dan Penampilan Pasar Wortel di Sub Terminal Agrobisnis (STA) Mantung (Kasus pada Sentra Produksi Wortel di Desa Tawangsari, Kecamatan Pujon, Kabupaten Malang). Agricultural SocioEconomics Journal, 12(2), 91.

9. Rayid, S., dkk. (2005). Kewirausahaan Santri, (PT. Citrayudha, Jakarta, 2005).

10. Hendro. (2005). How To Become A Smart Entrepreneurship And To Start A New Busines, (Andi Offset, Yogyakarta, 2005)

11. Wiyani, N. A. Teacherpreneurship. Yogyakarta: Ar Ruzz Media. 